\title{
ANALISIS RUTE TRANSPORTASI SAMPAH KOTA BAUBAU MENGGUNAKAN SAVING HEURISTIC
}

\section{ANALISYS OF GARBAGE TRANSPORTATION ROUTE OF BAUBAU CITY USING SAVING HEURISTIC METHOD}

\author{
Ahmad Efendi ${ }^{1}$, Syamsul Bahri Bahar ${ }^{2}$, Idwan $^{3}$ \\ ${ }^{123}$ Program Studi Teknik Sipil, Fakultas Teknik, Universitas Muhammadiyah Buton \\ Jl. Betoambari No. 36 Kota Baubau, Sulawesi Tenggara, Indonesia, (0402) 2827038 \\ Email: fahlan.efendi@gmail.com
}

\begin{abstract}
The problem of garbage in the town of Baubau is the large number of piles as a result of the inability of garbage in tubs. The target to be achieved is to know the pattern of transport routes transporting an effective garbage. The method used is a saving heuristic. The results showed that line 1 in Murhum to route all service as far as $27 \mathrm{~km}$ with operational costs of $\mathrm{Rp}$. $27.500 /$ day, twice the service route as far as $50,62 \mathrm{~km}$ with operational costs of Rp. 44.000 route/day and three times as far as 74,05 $\mathrm{km}$ with operational costs of Rp. 66.000/day. Line 2 in Murhum to route all service as far as $24,47 \mathrm{~km}$ with operational costs of Rp. $27.500 / \mathrm{day}$, twice the service route as far as $25,88 \mathrm{~km}$ with operational costs of Rp. 44.000 route/day and three times as far as $71,58 \mathrm{~km}$ and costs Rp. 66.000/day. While in the Batupoaro, the route once the service as far as $26,21 \mathrm{~km}$ with operational costs of Rp 27.500/day, twice the service

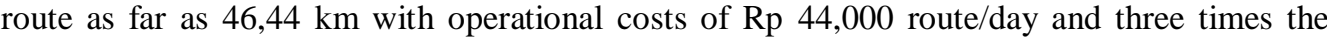
service so far $68.49 \mathrm{~km}$ and costs Rp. 60.500/day.
\end{abstract}

Keywords: Transportation Route, Garbage, Saving Heuristic

\begin{abstract}
Abstrak
Masalah persampahan di Kota Baubau adalah banyaknyak timbulan sampah yang terdapat di jalan-jalan sebagai akibat dari ketidakmampuan bak sampah dalam menampung sampah masyarakat. Target yang ingin dicapai adalah untuk mengetahui pola rute transportasi pengangkutan sampah yang efektif sehingga berimplikasi terhadap penurunan biaya operasional yang harus ditanggung oleh Dinas Lingkungan Hidup Kota Baubau. Metode yang digunakan adalah metode saving heuristic. Hasil penelitian diperoleh pada jalur 1 Kecamatan Murhum untuk rute sekali pelayanan sejauh $27,00 \mathrm{~km}$ dengan biaya operasional $\mathrm{Rp}$ $27.500,00 /$ hari, rute dua kali pelayanan sejauh $50,62 \mathrm{~km}$ dengan biaya operasional $\mathrm{Rp}$ $44.000,00 /$ hari dan rute tiga kali pelayanan sejauh 74,05 km dengan biaya operasional $\mathrm{Rp}$ 66.000,00/hari. Jalur 2 Kecamatan Murhum untuk rute sekali pelayanan sejauh 24,47 km dengan biaya operasional Rp 27.500,00/hari, rute dua kali pelayanan sejauh 25,88 km dengan biaya operasional $\mathrm{Rp} 44.000,00 /$ hari dan rute tiga kali pelayanan sejauh $71,58 \mathrm{~km}$ dengan biaya operasional Rp 66.000,00/hari. Sedangkan Kecamatan Batupoaro, rute sekali pelayanan sejauh $26,21 \mathrm{~km}$ dengan biaya operasional Rp 27.500,00/hari, rute dua kali pelayanan sejauh 46,44 $\mathrm{km}$ dengan biaya operasional $\mathrm{Rp} 44.000,00 /$ hari dan rute tiga kali pelayanan sejauh $68,49 \mathrm{~km}$ dengan biaya operasional $\mathrm{Rp} 60.500,00 /$ hari.
\end{abstract}

Kata kunci: Rute Transportasi, Sampah, Saving Heuristic

\section{PENDAHULUAN}

Kota Baubau merupakan salah satu kotamadya yang sedang berkembang di Sulawesi Tenggara dengan tingkat pertumbuhan penduduk yang tinggi.Tingginya tingkat pertumbuhan penduduk menyebabkan timbulnya masalah persampahan di Kota Baubau.Masalah persampahan di Kota Baubau adalah banyaknyak timbulan-timbulan sampah yang terdapat di jalan-jalan sebagai akibat dari ketidakmampuan bak sampah dalam menampung sampah-sampah masyarakat. Hasil penelitian; Suhardimo (2014), pada Kecamatan Batupoaro Kota Baubau diperoleh rata-rata timbulan sampah sebesar 
54.428,90 liter/hari dengan jumlah mobil operasional persampahan yang beroperasi di Kecamatan Batupoaro adalah 2 unit mobil Dump truck dan 1 unit Open Cup dengan pelayanan 1 kali sehari sehingga timbulan sampah di Kecamatan Batupoaro tidak dapat terlayani.

Berdasarkan Peraturan Daerah Kota Baubau Nomor 12 Tahun 2002 tentang Pengeloaan Persampahan/Kebersihan, maka yang bertanggung jawab dalam hal pengelolaan dan pengangkutan sampah di Kota Baubau adalah Dinas Kebersihan yang saat ini telah berubah nama menjadi Dinas Lingkungan Hidup. Secara umum kebijakan pengelolaan sampah di Kota Baubau masih mengikuti paradigma lama, yaitu sampah dikumpulkan, kemudian diangkut dan akhirnya dibuang ke Tempat Pembuangan Akhir (TPA). Kondisi sampah yang dihasilkan masyarakat Kota Baubau yang tinggi tentu saja membutuhkan alat angkut yang banyak, namun kondisi Dinas Lingkungan Hidup Kota Baubau saat ini hanya memiliki alat angkut yang terbatas dan harus melayani seluruh wilayah Kota Baubau sehingga satu alat angkut akan melayani beberapa daerah pelayanan.

Kondisi tersebut menyebabkan masih adanya sampah yang tidak terangkut ke TPA sehingga menimbulkan bau busuk yang menyengat yang dikhawatirkan dapat mengganggu kesehatan masyarakat setempat.Selain itu, dengan kondisi yang ada menyebabkan tingginya tingkat konsumsi bahan bakar alat angkut yang berimbas pada besarnya biaya operasional yang harus ditanggung oleh Lingkunagn Hidup Kota Baubau.Hal ini menandakan bahwa tingkat pelayanan pengangkutan sampah yang dilakukan oleh Dinas Lingkungan Hidup Kota Baubau masih belum efektif.

Berdasarkan uraian-uraian tersebut, maka permasalahan yang akan dikaji dalam penelitian ini adalah bagaimana pola rute pelayanan pengangkutan sampah yang efektif di Kota Baubau dan berapa besar biaya operasional yang harus ditanggung oleh Dinas Lingkungan Hidup Kota Baubau yang diakibatkan oleh pola rute pelayanan. Adapun batasan masalah dalam penelitian ini adalah:

- Penumpukan sampah pada beberapa Tempat Pembuangan Sementara yang tersebar di wilayahKota Baubau
- Pola pengangkutan door to door dengan mobil dump truck yang berkapasitas 6000 liter atau $6 \mathrm{~m}^{3}$.

- Kondisi jarak dari jarak titik A ke titik B tidak sama dengan kondisi jarak dari titik B ke titik A.

- Pelayanan yang dilakukan terbagi 3 (tiga) pelayanan yaitu satu kali pelayanan, dua kali pelayanan, dan tiga kali pelayanan.

\section{Pengertian dan Pengolahan Sampah}

Secara umum sampah dapat dikategorikan menjadi dua, yaitu sampah sebagai limbah padat dan sampah sebagai sumber daya. Sampah sebagai limbah padat apabila tidak dikelola dengan baik akan mengakibatkan permasalahan seperti pencemaran lingkungan dan sumber penyakit. Sedangkan sampah sebagai sumber daya merupakan sampah yang memiliki potensi untuk dimanfaatkan sehingga mempunyai nilai tambah sebagai produk daur ulang yang memiliki nilai ekonomi.

Menurut Hadiwiyoto (Sejati, 2009) penggolongan sampah dapat didasarkan atas beberapa kriteria, yaitu:

- Penggolongan sampah berdasarkan asalnya

- Penggolongan sampah berdasarkan komposisinya

- Penggolongan sampah berdasarkan bentuknya

- Penggolongan sampah berdasarkan lokasinya

- Penggolongan sampah berdasarkan proses terjadinya

- Penggolongan sampah berdasarkan sifatnya

- Penggolongan sampah berdasarkan jenisnya

\section{Pengangkutan Sampah}

Pengangkutan sampah adalah kegiatan atau proses pemindahan sampah dari satu tempat atau berbagi tempat kesuatu lokasi pengumpulan sampah tersebut (Anonim 2002).Pengangkutan sampah merupakan salah satu komponen penting dan membutuhkan perhitungan yang cukup teliti, dengan sasaran mengoptimalkan waktu angkut yang diperlukan dalam sistem tersebut.

Operasi pengangkutan yang ekonomis ditentukan oleh beberapa faktor antara lain: 
- Dipilih rute yang sependek-pendeknya dan sedikit hambatan

- Mempergunakan truk yang kapasitas daya angkut maksimal yang memungkinkan

- Mempergunakan kendaraan yang hemat bahan bakar

- Jumlah trip pengangkutan sebanyak mungkin dalam waktu yang di izinkan

Untuk sistem door-to-door, yaitu pengumpulan sekaligus pengangkutan sampah, maka sistem pengangkutan sampah dapat menggunakan pola pengangkutan sebagai berikut:

- Kendaraan keluar dari pool dan langsung menuju ke jalur pengumpulan sampah

- Truk sampah berhenti di pinggi jalan di setiap rumah yang akan dilayani, dan pekerja mengambil sampah serta mengisih bak truk sampai penuh.

- Setelah terisi penuh truk langsung menuju ketempat pemerosesan atau ke TPA. Dari lokasi pemerosesan tersebut, kendaraan kembali kejalur pelayanan berikutnya sampai shift terakhir, kemudian kembali ke pool.

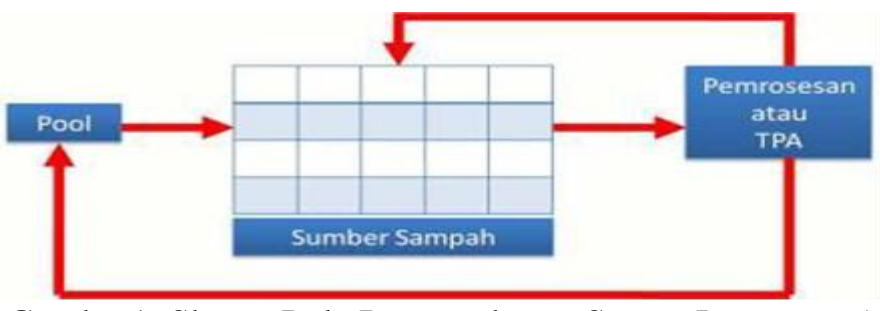

Gambar1. Skema Pola Pengangkutan Secara Langsung (Door-to-door)

\section{Transportasi}

Transportasi membahas masalah pendistribusian suatu komoditas atau produk dari sejumlah sumber (supply) kepada jumlah tujuan (destination, demand), dengan tujuan meminimumkan ongkos pengangkutan yang terjadi (Tjutju dan Ahmad Dimyati, 2004). Ciri-ciri khusus persoalan transportasi ini adalah sebagai berikut:

- Terdapat sejumlah sumber dan sejumlah tujuan tertentu.

- Kuantitas komoditas yang didistribusikan dari setiap sumber dan yang diminta oleh setiap tujuan, besarnya tertentu.

- Komoditas yang dikirim atau diangkut dari suatu sumber ketujuan tertentu, besarnya sesuai dengan permintaan dan atau kapasitas sumber.

- Ongkos pengangkutan komoditas dari suatu sumber kesuatu tujuan, besarnya tertentu.

Masalah umum dalam transportasi adalah perencanaan rute untuk kendaraan atau orang dalam melakukan perjalanan dari tempat asal ke tempat tujuan. Beberapa contoh kasus penentuan rute yang harus direncanakan dalam satu wilayah atau daerah khusus dari sebuah kota, misalnya rute kendaraan pengangkut sampah, rute distribusi surat kabar, rute pengambilan surat di box-box surat, rute pengambilan coin telepon umum, dan lain sebagainya.

\section{Vehicle Routing Problem (VRP)}

Vehicle Routhing Problem (VRP) diperkenalkan pertamakali oleh Dantziq dan Ramser pada tahun 1959. VRP didefenisikan sebagai sebuah pencarian atas cara penggunaan yang efisien dari sejumlah vihicle yang harus melakukan perjalanan untuk mengunjungi sejumlah tempat untuk mengantar dan/atau menjemput orang/barang. VRP juga dapat dilihat sebagai kombinasi dari dua permasalahan optimasi lain, yaitu Bin Packing Problem (BPP) dan Travelling Salesmen Problem (TSP).

Masalah pencarian solusi yang baik dalam masalah penentuan kendaraan menjadi lebih sulit dengan adanya pembatas-pembatas tambahan dari masalah. Salah satu solusi dalam VRP untuk memecahkan masalah rute adalah dengan menggunakan metode Saving Heuristic. Metode ini pertama kali diperkenalkan oleh Clarke dan Wright pada tahun 1964 dengan mempublikasikan sebuah alogaritma sebagai solusi permasalahan dari berbagai rute kendaraan, yang sering disebut sebagai permasalahan klasik dari rute kendaraan (the classical vehicle routing problem). Alogaritma ini didasari pada suatu konsep yang disebut konsep savings. 
Saving heuristic adalah prosedur pengulangan yang pertama kali menghasilkan rute yang jelas dimana masing-masingnya melayani satu pelanggan.Pada setiap iterasi berikutnya, algoritma mencoba untuk menggabungkan pasangan rute supaya diperoleh pengurangan biaya (penghematan).Penghematan biaya $\left(S_{\mathrm{ij}}\right)$ diperoleh bila melayani pelanggan (i) dan (j). $\mathrm{I}, \mathrm{j} \in \mathrm{U}$ berada pada satu rute. Persamaan saving heuristic adalah:

Dimana:

$$
S_{i j}=c_{1 i}+c_{1 j}-c_{i j}
$$

$$
\begin{array}{ll}
\mathrm{i} \text { dan } \mathrm{j} & =\text { nodes } 2,3, \mathrm{~K}, \mathrm{n} \\
\mathrm{c}_{\mathrm{ij}} & =\text { jarak perjalanan dari node } \mathrm{i} \\
& \text { ke node } \mathrm{j}
\end{array}
$$

(Sumber : Ghianni, Laporte dan Musmanno, 2004)

\section{METODE PENELITIAN}

Langkah-langkah dalam melakukan analisis terhadap data dalam penelitian ini dengan menggunakan Saving Heuristic adalah sebagai berikut :
- Pilih salah satu node sebagai depot node (node 1).

- Hitung Savings, $S_{\mathrm{ij}}$ untuk jaringan antara nodes $i$ dan $j$ menggunakan persamaan $S_{i j}=c_{1 \mathrm{j}}+c_{1 \mathrm{j}}-c_{i j}$.

- Urutkan savings dalam bentuk tabel mulai dari yang terbesar sampai yang terkecil.

- Urutkan rute yang dimulai dari savings yang terbesar hingga ke urutan yang terkecil dan dituliskan dalam bentuk tabel dan hubungkan antara node i dan node $\mathrm{j}$.

- Berhenti ketika sebuah Rute yang utuh telah dibentuk dan sesuaikan permintaan dengan kapasitas pengiriman. Dalam membentuk Rute, titik awal dan akhir harus berada pada satu titik yang sama yang merupakan depot.

Adapun langkah-langkah pemecahan masalah menggunakan saving heuristic diperlihatkan pada gambar 2 berikut

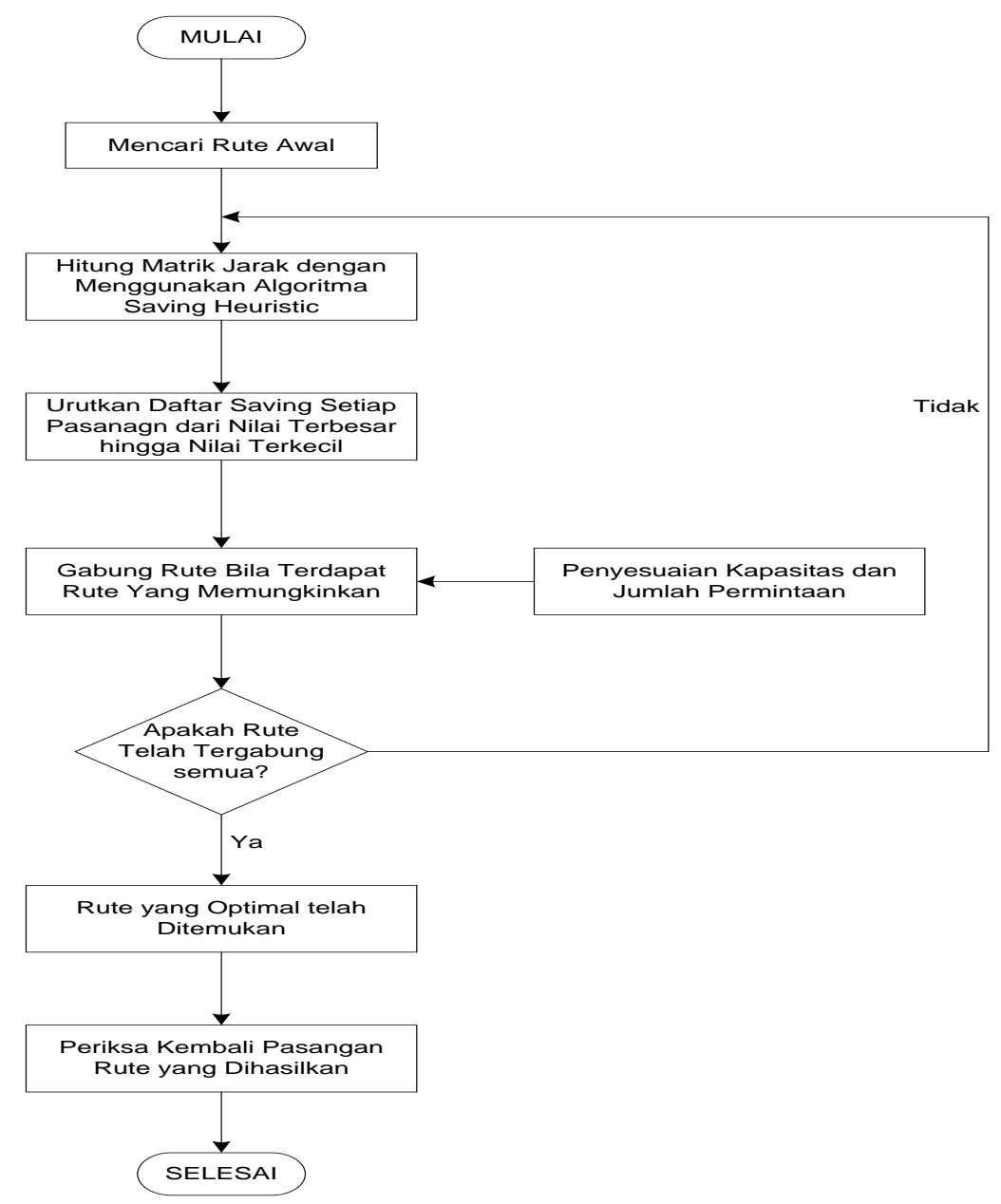

Gambar 2. Flowchart Saving Heuristic 


\section{HASIL DAN PEMBAHASAN}

Jalur 1 Kecamatan Murhum

Jalur 1 Kecamatan Murhum terdiri dari 22 TPS yang tersebar di tiga jalan yaitu Jalan La Buke dengan jumlah TPS sebanyak 11 TPS, Jalan Drs. H. La Ode Manarfa dengan jumlah TPS sebanyak 7 TPS dan Jalan Sultan La Buke dengan TPS sejumlah 4 TPS. Dengan TPS sejumlah 22 TPS pada jalur 1 Kecamatan Murhum, menghasilkan timbulan sampah sebesar 6,29 $\mathrm{m}^{3}$.Berdasarkan survey pengamatan dan wawancara yang dilakukan, diketahui bahwa seluruh TPS yang berada di jalur 1 Kecamatan Murhum mayoritas terlayani dalam sekali pelayanan.namun pada kondisikondisi tertentu terkadang timbulan sampah terlayani dalam dua kali dan bahkan tiga kali pelayanan dalam sehari.Pelayanan sampah dua kali dan tiga kali hanya terjadi dalam kondisi-kondisi atau situasi tertentu saja.

\section{Rute Awal Jalur 1 Kecamatan Murhum}

Rute awal ini merupakan rute yang sering dilalui oleh alat angkut (dump truck) dalam pelayanan sampah yang dilakukan oleh alat angkut baik untuk sekali pelayanan maupun lebih. Rute awal ini terbagi dalam:

- Rute awal untuk satu kali pelayanan

Tabel 1. Rute Awal untuk satu kali pelayanan

\begin{tabular}{ccc}
\hline Jalur & \multicolumn{1}{c}{ Rute } & Jarak (Km) \\
\hline Rute 1 & Pool-1-2-3-4-5-6-7-8-9-10-11-12-13-14- & 28,19 \\
& 15-16-17-18-19-20-21-22-TPA-Pool & \\
\hline \multicolumn{3}{c}{ Total Jarak } \\
\hline
\end{tabular}

- Rute awal untuk dua kali pelayanan

Tabel 2. Rute awal untuk dua kali pelayanan

\begin{tabular}{ccc}
\hline Jalur & Rute & Jarak (Km) \\
\hline Rute 1 & Pool-1-2-3-4-5-6-7-8-9-10-11-TPA-Pool & 28,06 \\
\hline Rute 2 & Pool-12-13-14-15-16-17-18-19-20-21-22-TPA-Pool & 25,11 \\
\hline & Total Jarak & $\mathbf{5 3 , 1 7}$ \\
\hline
\end{tabular}

- Rute awal untuk tiga kali pelayanan

Tabel 3. Rute awal untuk tiga kali pelayanan

\begin{tabular}{clc}
\hline Jalur & \multicolumn{1}{c}{ Rute } & Jarak (Km) \\
\hline Rute 1 & Pool-1-2-3-4-5-6-7-TPA-Pool & 26.08 \\
\hline Rute 2 & Pool-8-9-10-11-12-13-14-15-16-17-18-19-TPA-Pool & 27.23 \\
\hline Rute 3 & Pool-20-21-22-TPA-Pool & 22.45 \\
\hline \multicolumn{2}{c}{ Total Jarak } & $\mathbf{7 5 , 7 6}$ \\
\hline
\end{tabular}

\section{Rute Hasil SavingHeuristic Jalur 1 Kecamatan Murhum \\ Dalam menentukan rute} menggunakan metode savingHeuristic adalah menentukan nilai saving dari matriks jarak menggunakan persamaan $S_{i j}=\boldsymbol{c}_{\mathbf{1 j}}+\boldsymbol{c}_{\mathbf{1 j}}-\boldsymbol{c i j}$. Setelah mendapatkan hasil perhitungan saving, selanjutnya melakukan perengkingan terhadap hasil perhitungan saving. Hasil perengkingan ini nantinya akan digunakan dalam menentukan rute baru hasil perhitungan nilai saving.
Tabel 4. Rangking Saving1-10

\begin{tabular}{llll}
\hline No & Rangking & Koordinat & Saving \\
\hline 1 & 1 & TPA, 11 & 8,52 \\
2 & 2 & TPA 12 & 8,37 \\
3 & 3 & TPA, 13 & 8,34 \\
4 & 4 & TPA, 9 & 9,11 \\
5 & 5 & TPA, 14 & 8,36 \\
6 & 6 & TPA, 15 & 8,38 \\
7 & 7 & TPA, 10 & 8,62 \\
8 & 8 & TPA, 8 & 9,23 \\
9 & 9 & TPA, 7 & 9,24 \\
10 & 10 & TPA, 16 & 8,23 \\
\hline
\end{tabular}

Berdasarkan hasil dari perengkingan nilai saving yang telah dilakukan, maka ditentukanlah rute hasil saving. Adapun rute hasil saving adalah sebagai berikut:

a. Rute hasil Saving Heuristic untuk satu kali pelayanan 
Tabel 5. Rute Hasil Saving Heurstic untuk sekali pelayanan

\begin{tabular}{|c|c|c|c|}
\hline Jalur & Rute & Jarak (Km) & $\begin{array}{c}\text { Sampah } \\
\text { Terangkut }\left(\mathrm{m}^{3}\right)\end{array}$ \\
\hline Rute 1 & $\begin{array}{l}\text { Pool-22-21-20-19-6-1-2-3-4-5-11-18-12- } \\
\text { 13-14-15-16-17-10-8-7-9-TPA-Pool }\end{array}$ & 27,00 & 6,29 \\
\hline & Total Jarak & 27,00 & 6,29 \\
\hline
\end{tabular}

Berdasarkan hasil perhitungan saving, diperoleh total jarak tempuh alat angkut sejauh 27,00 Km dengan jumlah sampah yang terangkut sebesar $6,29 \mathrm{~m}^{3}$. Hal ini menandakan bahwa terjadi penghematan total jarak tempuh sebesar $1,19 \mathrm{Km}$ dari jarak tempuh awal yang dilalui alat angkut yakni sejauh $28,19 \mathrm{Km}$. Berdasarkan rute hasil SavingHeuristicyang diperoleh maka biaya operasional(pemakaian bahan bakar) untuk satu kali pelayanan sampah (pelayanan diperoleh: $\frac{27 \mathrm{~km}}{6,5 \mathrm{~km}} \times R p 5.500=$

$R p$ 22.846,15 atau 4,15 liter

Untuk menghindari nilai decimal pada biaya operasional, maka Dinas Lingkungan Hidup dapat mengalokasikan biaya operasional (biaya bahan bakar) alat angkut untuk 5 liter sehingga diperoleh besaran biaya operasional (biaya bahan bakar) sebesar 5 liter x Rp $5.500=\mathrm{Rp}$ 27.500,00/hari atau Rp 55.000,00 untuk 2 hari.

b. Rute untuk dua kali pelayanan

Tabel 6. Rute hasil SavingHeuristic untuk dua kali pelayanan

\begin{tabular}{ccc}
\hline Jalur & Rute & Jarak $(\mathbf{K m})$ \\
\hline Rute 1 & Pool-11-12-13-14-15-16-17-10-9-8-7-TPA-Pool & 26,04 \\
Rute 2 & Pool-22-21-20-19-6-1-2-3-4-5-18-TPA-Pool & 24,58 \\
\hline \multicolumn{3}{c}{ Total Jarak } \\
\hline
\end{tabular}

Berdasarkan rute hasil SavingHeuristicyang diperoleh maka biaya operasional(pemakaian bahan bakar) untuk dua kali pelayanan sampah (pelayanan pagi dan sore) diperoleh: $\frac{50,62 \mathrm{~km}}{6,5 \mathrm{~km}} \times R p 5.500=$ $R p$ 42.832,31 atau 7,79 liter

Untuk menghindari nilai decimal pada biaya operasional, maka Dinas
Lingkungan Hidup dapat mengalokasikan biaya operasional (biaya bahan bakar) alat angkut untuk 8 liter sehingga diperoleh besaran biaya operasional (biaya bahan bakar) sebesar 8 liter $\mathrm{x}$ Rp $5.500=\mathrm{Rp}$ 44.000,-/hari atau $\operatorname{Rp~88.000,00~untuk~} 2$ hari.

c. Rute untuk tiga kali pelayanan

Tabel 7.Rute hasil savingHeuristic untuk tiga kali pelayanan

\begin{tabular}{clc}
\hline Jalur & \multicolumn{1}{c}{ Rute } & Jarak $\mathbf{( K m})$ \\
\hline Rute 1 & Pool-17-16-15-14-13-12-11-9-10-8-7-TPA-Pool & 25,44 \\
Rute 2 & Pool-18-6-5-4-3-2-1-TPA-Pool & 26,07 \\
Rute 3 & Pool-22-20-19-21-TPA-Pool & 22,54 \\
\hline & Total Jarak & $\mathbf{7 4 , 0 5}$ \\
\hline
\end{tabular}

\begin{tabular}{|c|c|}
\hline $\begin{array}{lcr}\text { Berdasarkan } & \text { rute } & \text { hasil } \\
\text { SavingHeuristicyang diperoleh } & \text { maka } \\
\text { biaya operasional(pemakaian } & \text { bahan } \\
\text { bakar) untuk tiga kali pelayanan sampah } \\
\text { (pelayanan pagi, siang dan sore) }\end{array}$ & $\begin{array}{l}\text { angkut untuk } 12 \text { liter sehingga diperoleh } \\
\text { besaran biaya operasional (biaya bahan } \\
\text { bakar) sebesar } 12 \text { liter x Rp } 5.500=\mathrm{Rp} \\
66.000 \text {,-/hari atau Rp } 132.000,- \text { untuk } 2 \\
\text { hari. }\end{array}$ \\
\hline
\end{tabular}
diperoleh: $\frac{74,05 \mathrm{~km}}{6,5 \mathrm{~km}} \times R p 5.500=$ $R p$ 62.657,69 atau 11,39 liter

Agar tidak memperoleh nilai decimal pada biaya operasional, maka Dinas Lingkungan Hidup dapat mengalokasikan biaya operasional (biaya bahan bakar) alat

\section{Jalur 2 Kecamatan Murhum}

Jalur 2 Kecamatan Murhum terdiri dari 79 TPS yang tersebar di delapan jalan yaitu Jalan Labalawo dengan jumlah TPS sebanyak 9 TPS, Jalan Gajah Mada dengan 
jumlah TPS sebanyak 20 TPS, Jalan Sultan Murhum dengan TPS sejumlah 3 TPS , Jalan HOS. Cokroaminoto dengan TPS sejumlah 6 TPS, Jalan DR. Wahidin. S dengan jumlah TPS sebanyak 10 TPS, Jalan Sijawangkati dengan TPS sejumlah 9 TPS, Jalan Wa Ode Wau dengan jumlah TPS sejumlah 9 TPS dan Jalan Limbo Wolio dengan TPS sejumlah 13 TPS. Dengan TPS sejumlah 79 TPS pada jalur 2 Kecamatan Murhum, menghasilkan timbulan sampah sebesar $6,93 \mathrm{~m}^{3}$.

Berdasarkan timbulan sampah pada jalur 1 Kecamatan Murhum sebesar 6,93 $\mathrm{m}^{3}$, maka jalur 2 Kecamatan Murhum sebagai berikut:

\section{Rute Awal Jalur 2 Kecamatan Murhum}

a. Rute awal untuk satu kali pelayanan (pagi)

Tabel 8. Rute awal untuk satu kali pelayanan (pagi)

\begin{tabular}{ccc}
\hline Jalur & \multicolumn{1}{c}{ Rute } & Jarak (Km) \\
\hline Rute 1 & Pool-1-2-3-4-5-6-7-8-9-10-11-12-13-14-15-16-17-18-19-20-21- & 27,91 \\
& $22-23-24-25-26-27-28-29-30-31-32-33-34-35-36-37-38-39-40-$ & \\
& $41-42-43-44-45-46-47-48-49-50-51-52-53-54-55-56-57-58-59-$ & \\
& 60-61-62-63-64-65-66-67-68-69-70-71-72-73-74-75-76-77-78- & \\
& & \\
\hline & & $\mathbf{2 7 , 9 1}$ \\
\hline
\end{tabular}

b. Rute awal untuk dua kali pelayanan (pagi dan sore)

Tabel 9. Rute awal untuk dua kali pelayanan

\begin{tabular}{ccc}
\hline Jalur & \multicolumn{1}{c}{ Rute } & Jarak (Km) \\
\hline Rute 1 & Pool-1-2-3-4-5-6-7-8-9-10-11-12-13-14-15-16-17-18-19-20-21-22-23-24- & 27,81 \\
& $25-26-27-28-29-30-31-32-33-34-35-36-37-38-39-40-T P A-P o o l$ & \\
\hline \multirow{2}{*}{ Rute 2 } & Pool-41-42-43-44-45-46-47-48-49-50-51-52-53-54-55-56-57-58-59-60- & 24,71 \\
& 61-62-63-64-65-66-67-68-69-70-71-72-73-74-75-76-77-78-79-TPA-Pool & \\
\hline & Total Jarak & $\mathbf{5 2 , 5 2}$ \\
\hline
\end{tabular}

c. Rute awal untuk tiga kali pelayanan (pagi, siang dan sore)

Tabel 10. Rute awal untuk tiga kali pelayanan (pagi, siang dan sore)

\begin{tabular}{clc}
\hline Jalur & \multicolumn{1}{c}{ Rute } & Jarak (Km) \\
\hline Rute 1 & $\begin{array}{l}\text { Pool-1-2-3-4-5-6-7-8-9-10-11-12-13-14-15-16-17-18- } \\
\text { 19-20-21-22-23-24-25-26-TPA-Pool }\end{array}$ & 26,12 \\
\hline Rute 2 & $\begin{array}{l}\text { Pool-27-28-29-30-31-32-33-34-35-36-37-38-39-40-41- } \\
\text { 42-43-44-45-46-47-48-49-50-51-52-TPA-Pool }\end{array}$ & 25,01 \\
\hline Rute 3 & $\begin{array}{l}\text { Pool-53-54-55-56-57-58-59-60-61-62-63-64-65-66-67- } \\
\text { 68-69-70-71-72-73-74-75-76-77-78-79-TPA-Pool }\end{array}$ & 22,04 \\
\hline \multicolumn{2}{c}{ Total Jarak } & $\mathbf{7 3 , 1 8}$ \\
\hline
\end{tabular}

\section{Rute Hasil Saving Huristic Jalur 2 Kecamatan Murhum \\ Dalam menentukan rute hasil} SavingHeuristic matriks jarak menggunakan persamaan $S_{i j}=c_{1 \mathrm{j}}+\boldsymbol{c}_{1 \mathrm{j}}-\boldsymbol{c}_{i j} \mathrm{rti}$ pada jalu 1 Kecamatan Murhum. Selanjutnya perengkingan terhadap hasil perhitungan saving dilakukan yang nantinya akan digunakan dalam menentukan rute baru hasil perhitungan berdasarkan nilai saving.
Tabel 11 Rangking 1-15 Hasil Saving

\begin{tabular}{lccc}
\hline No & Rangking & Koordinat & Saving \\
\hline 1 & 1 & 17.16 & 9.78 \\
2 & 2 & 19.16 & 9.78 \\
3 & 3 & 20.16 & 9.78 \\
4 & 4 & 21.16 & 9.78 \\
5 & 5 & 22.16 & 9.78 \\
6 & 6 & 7.8 & 8.33 \\
7 & 7 & 7.9 & 8.33 \\
8 & 8 & 7.10 & 8.33 \\
9 & 9 & 7.11 & 8.33 \\
10 & 10 & 7.12 & 8.33 \\
11 & 11 & 7.13 & 8.33 \\
12 & 12 & 7.14 & 8.33 \\
13 & 13 & 7.15 & 8.33 \\
14 & 14 & 7.16 & 8.33 \\
15 & 15 & 7.17 & 8.33 \\
\hline
\end{tabular}


Berdasarkan hasil dari perengkingan nilai saving yang telah dilakukan, maka a. Rute hasil savingHeuristic untuk sekali palayanan (pagi)

Tabel 12. Rute Hasil Saving Heurstic untuk sekali pelayanan di Jalur 2 Kecamatan Murhum

\begin{tabular}{|c|c|c|c|}
\hline Jalur & Rute & $\begin{array}{l}\text { Jarak } \\
(\mathbf{K m})\end{array}$ & $\begin{array}{c}\text { Sampah } \\
\text { Terangkut }\left(\mathrm{m}^{3}\right)\end{array}$ \\
\hline Rute 1 & $\begin{array}{l}\text { Pool-22-21-20-19-18-17-16-15-14-13-12-11-10-9-8-7-79-78-77- } \\
\text { 76-75-74-73-72-71-70-69-68-67-66-65-64-63-62-61-60-59-58-57- } \\
56-55-54-53-52-51-50-49-48-47-46-45-44-43-42-41-40-39-38-37- \\
6-5-4-3-2-1-23-24-25-26-27-28-29-30-31-32-33-34-35-36-T P A- \\
\text { Pool }\end{array}$ & 27,47 & 6,93 \\
\hline \multicolumn{2}{|r|}{ Total Jarak } & 27,47 & 6,93 \\
\hline
\end{tabular}

Berdasarkan hasil perhitungan saving, diperoleh total jarak tempuh alat angkut sejauh $27,47 \mathrm{Km}$ dengan jumlah sampah yang terangkut sebesar $6.93 \mathrm{~m}^{3}$. Hal ini menandakan bahwa terjadi penghematan total jarak tempuh sebesar $0,44 \mathrm{Km}$ dari jarak tempuh awal yang dilalui alat angkut yakni sejauh 27,91 Km. Berdasarkan rute hasil SavingHeuristicyang diperoleh maka biaya operasional(pemakaian bahan bakar) untuk satu kali pelayanan sampah (pelayanan pagi) diperoleh: $\frac{27,47 \mathrm{~km}}{6,5 \mathrm{~km}} \times R p 5.500=$

$R p 23.243,85$ atau 4,23 liter ditentukanlah rute hasil saving. Adapun rute hasil saving adalah sebagai berikut:

Tabel 13. Rute hasil SavingHeuristic untuk dua kali pelayanan di jalur Kecamatan Murhum

\begin{tabular}{clc}
\hline Jalur & \multicolumn{1}{c}{ Rute } & Jarak $(\mathbf{K m})$ \\
\hline Rute 1 & Pool-22-21-20-19-18-17-16-15-14-13-12-11-10-9-8-7- & 25,88 \\
& $79-78-77-76-75-74-73-72-71-70-69-68-67-66-65-64-$ & \\
& $63-62-61-60-59-58-57-56-T P A-P o o l$ & 23,53 \\
\hline Rute 2 & Pool-55-54-53-52-51-50-49-48-47-46-45-44-43-42- & \\
& $41-40-39-38-37-6-5-4-3-2-1-23-24-25-26-27-28-29-$ & \\
& $30-31-32-33-34-35-36-T P A-P o o l$ & \\
\hline
\end{tabular}

pada biaya operasional, maka Dinas Lingkungan Hidup dapat mengalokasikan biaya operasional (biaya bahan bakar) alat angkut untuk 5 liter sehingga diperoleh besaran biaya operasional (biaya bahan bakar) sebesar 5 liter x Rp $5.500=\mathrm{Rp}$ 27.500,00/hari atau $\mathrm{Rp} \mathrm{55.000,00} \mathrm{untuk} 2$ hari.

b. Rute hasil savingHeuristic untuk dua kali pelayanan (pagi dan sore)

\begin{tabular}{lrr}
\hline & \multicolumn{2}{c}{ Total Jarak } \\
\hline Berdasarkan rute & hasil \\
ingHeuristicyang diperoleh & maka \\
a operasional(pemakaian bahan & bahan \\
ar) untuk dua kali pelayanan sampah \\
ayanan pagi $\quad$ dan & sore) \\
roleh: $\frac{49,41 \mathrm{~km}}{6,5 \mathrm{~km}} \times R p$ & $5.500=$
\end{tabular}

$R p$ 41.808,46 atau 7,60 liter

Untuk menghindari nilai decimal pada biaya operasional, maka
Dinas Lingkungan Hidup dapat mengalokasikan biaya operasional (biaya bahan bakar) alat angkut untuk 8 liter sehingga diperoleh besaran biaya operasional (biaya bahan bakar) sebesar 8 liter $x \operatorname{Rp} 5.500=\operatorname{Rp} 44.000 /$ hari atau Rp 88.000,00 untuk 2 hari.

c. Rute hasil Saving Heuristic untuk tiga kali pelayanan (pagi, siang dan sore) 
Tabel 14. Rute hasil savingHeuristic untuk tiga kali pelayanan

\begin{tabular}{|c|c|c|}
\hline Jalur & Rute & Jarak (Km) \\
\hline Rute 1 & $\begin{array}{l}\text { Pool-22-21-20-19-18-17-16-15-14-13-12-11-10-9-8-7- } \\
\text { 79-78-77-76-75-74-73-72-71-70-TPA-Pool }\end{array}$ & 24,38 \\
\hline Rute 2 & $\begin{array}{l}\text { Pool-69-68-67-66-65-64-63-62-61-60-59-58-57-56-55- } \\
\text { 54-53-52-51-50-49-48-47-46-45-44-TPA-Pool }\end{array}$ & 24,38 \\
\hline Rute 3 & $\begin{array}{l}\text { Pool-43-42-41-40-39-38-37-6-5-4-3-2-1-23-24-25-26- } \\
\text { 27-28-29-30-31-32-33-34-35-36-TPA-Pool }\end{array}$ & 22,82 \\
\hline & Total Jarak & 71,58 \\
\hline
\end{tabular}

Rute hasil Saving Heuristic yang terbentuk untuk rute 1 dan rute 2 mengalami penghematan jarak tempuh yang masing-masing $1,74 \mathrm{~km}$ pada rute 1 dan $0,63 \mathrm{~km}$ pada rute 2 . Namun penghematan jarak yang terjadi pada rute 1 dan rute 2 tidak terjadi pada rute 3 , dimana rute 3 tidak mengalami penghematan jarak namun mengalami pertambahan jarak dari rute awal yaitu sebesar $0,77 \mathrm{~km}$. Sebagai akibat dari pertambahan jarak yang terjadi pada rute 3 , maka total jarak tempuh untuk rute hasil saving Heuristic yang dilalui alat angkut (dump truck) hanya mengalami penghematan jarak sebesar 1,60 km dari rute awal.

Berdasarkan rute hasil SavingHeuristicyang diperoleh maka biaya operasional(pemakaian bahan bakar) untuk tiga kali pelayanan sampah (pelayanan pagi, siang dan sore) diperoleh: $\frac{71,58 \mathrm{~km}}{6,5 \mathrm{~km}} \times R p 5.500=$

$R p 60.567$ atau 11,01 liter

Agar tidak memperoleh nilai decimal pada biaya operasional, maka Dinas Lingkungan Hidup dapat mengalokasikan biaya operasional (biaya bahan bakar) alat angkut untuk 12 liter sehingga diperoleh besaran biaya operasional (biaya bahan bakar) sebesar 12 liter x Rp $5.500=$ Rp 66.000,-/hari atau Rp 132.000,- untuk 2 hari.

\section{Analisis Rute Kecamatan Batupoaro}

Rute pada jalur Kecamatan Batupoaro terdiri dari 55 TPS yang tersebar di tiga jalan yaitu Jalan Hayam Wuruk dengan jumlah TPS sebanyak 28 TPS, Jalan Dr. Wahidin. S dengan jumlah TPS sebanyak 3 TPS, dan Jalan Raja Wakaka dengan TPS sejumlah 24 TPS yang menghasilkan timbulan sampah sebesar $6,73 \mathrm{~m}^{3}$.

\section{Rute Awal Jalur Kecamatan Batupoaro}

Rute awal ini merupakan rute yang sering dilalui oleh alat angkut (dump truck) dalam pelayanan sampah yang dilakukan oleh alat angkut baik untuk sekali pelayanan maupun dua kali pelayanan di Kecamatan Batupoaro. Adapun rute awal untuk jalur Kecamatan Murhum adalah sebagai berikut:

a. Rute awal untuk satu kali pelayanan (pagi)

Tabel 15. Rute hasil savingHeuristic untuk satu kali pelayanan

\begin{tabular}{ccc}
\hline Jalur & Rute & Jarak (Km) \\
\hline Rute & Pool-1-2-3-4-5-6-7-8-9-10-11-12-13-14-15-16-17-18-19-20-21- & 26,83 \\
& $22-23-24-25-26-27-28-29-30-31-32-33-34-35-36-37-38-39-40-$ & \\
& $41-42-43-44-45-46-47-48-49-50-51-52-53-54-55-T P A-P o o l$ & \\
\hline \multicolumn{2}{c}{ Total Jarak } & $\mathbf{2 6 , 8 3}$ \\
\hline
\end{tabular}

Pada rute awal jalur Kecamatan Batupoaro dalam satu kali pelayanan (pagi) memiliki total jarak tempuh sejauh $26,83 \mathrm{~km}$ yang harus dilalui oleh alat angkut (dump truck). Dengan penghematan jarak tempuh alat angkut yang diperoleh dan berdasarkan hasil wawancara dengan pelaku (sumber: hasil wawancara dengan sopir dump truck) dimana diketahui bahwa biaya operasional kendaraan alat angkut (biaya bahan bakar) sebesar $\mathrm{Rp} 185.000,-$ untuk 25 liter yang digunakan dalam 2 hari pelayanan.

b. Rute awal untuk dua kali pelayanan (pagi dan sore) 
Tabel 16. Rute awal untuk dua kali pelayanan

\begin{tabular}{clc}
\hline Jalur & \multicolumn{1}{c}{ Rute } & Jarak (Km) \\
\hline Rute 1 & Pool-1-2-3-4-5-6-7-8-9-10-11-12-13-14-15-16-17-18-19-20- & 26,71 \\
& 21-22-23-24-25-26-27-28-TPA-Pool & \\
\hline Rute 2 & $\begin{array}{l}\text { Pool-29-30-31-32-33-34-35-36-37-38-39-40-41-42-43-44- } \\
\text { 45-46-47-48-49-50-51-52-53-54-55-TPA-Pool }\end{array}$ & 20,36 \\
\hline & \multicolumn{1}{c}{ Total Jarak } & $\mathbf{4 7 , 0 6}$ \\
\hline
\end{tabular}

Pada pelayanan sampah untuk dua kali pelayanan (pagi dan sore) terbentuk dua rute pelayanan yaitu rute 1 dengan jarak tempuh alat angkut sejauh $26,71 \mathrm{~km}$ dan rute 2 dengan jarak tempuh $20,36 \mathrm{~km}$

c. Rute awal untuk tiga kali pelayanan (pagi, siang dan sore)

Tabel 17. Rute awal untuk tiga kali pelayanan (pagi, siang dan sore)

\begin{tabular}{clc}
\hline Jalur & \multicolumn{1}{c}{ Rute } & Jarak (Km) \\
\hline Rute 1 & $\begin{array}{l}\text { Pool-1-2-3-4-5-6-7-8-9-10-11-12-13-14-15- } \\
\text { 16-17-18-TPA-Pool }\end{array}$ & 26,70 \\
\hline Rute 2 & $\begin{array}{l}\text { Pool-19-20-21-22-23-24-25-26-27-28-29-30- } \\
\text { 31-32-33-34-35-36-TPA-Pool }\end{array}$ & 22,05 \\
\hline Rute 3 & $\begin{array}{l}\text { Pool-37-38-39-40-41-42-43-44-45-46-47-48- } \\
\text { 49-50-51-52-53-54-55-TPA-Pool }\end{array}$ & 20,44 \\
\hline & \multicolumn{2}{c}{ Total Jarak } \\
\hline
\end{tabular}

Pada pelayanan sampah untuk tiga kali pelayanan (pagi, siang dan sore) terbentuk tiga rute pelayanan yaitu rute 1 dengan jarak tempuh alat angkut sejauh $26,70 \mathrm{~km}$ dan rute 2 dengan jarak tempuh $22,05 \mathrm{~km}$ serta rute 3 dengan jarak tempu sejauh 20,44 km.

Untuk operasional alat angkut (dump truck) di Kecamatan Batupoaro, Dinas Lingkungan Hidup menyiapkan 25 liter bahan bakar untuk dua hari baik untuk satu kali pelayanan, dua kali pelayanan maupun tiga kali pelayanan perhari. Harga bahan bakar solar yang berlaku saat ini adalah $\mathrm{Rp} 5.500$ maka biaya operasional perhari sebesar $\mathrm{Rp} 68.750$ atau Rp 137.500 untuk dua hari pelayanan.

\section{Rute Hasil SavingHeuristic Jalur Kecamatan Batupoaro}

Dalam menentukan rute hasil SavingHeuristic matriks jarak menggunakan persamaan $S_{i j}=c_{1 \mathrm{j}}+c_{1 \mathrm{j}}-c_{i j}$ rti pada Kecamatan Batupoaro. Adapun hasil perengkingan saving dari rangking 1 sampai dengan rangking 15 dapat di lihat pada 5.18 di bawah ini.

Tabel 18.Rangking 1-15 Hasil Saving

\begin{tabular}{cccc}
\hline No & Rangking & Koordinat & Saving \\
\hline 1 & 1 & 17,16 & 15,30 \\
\hline 2 & 2 & 19,16 & 15,30 \\
\hline 3 & 3 & 20,16 & 15,30 \\
\hline 4 & 4 & 21,16 & 15,30 \\
\hline 5 & 5 & 22,16 & 15,30 \\
\hline 6 & 6 & 3,4 & 10,20 \\
\hline 7 & 7 & 4,3 & 10,20 \\
\hline 8 & 8 & 5,4 & 9,99 \\
\hline 9 & 9 & 5,3 & 9,99 \\
\hline 10 & 10 & 3,5 & 9,94 \\
\hline 11 & 11 & 4,5 & 9,94 \\
\hline 12 & 12 & 3,2 & 9,10 \\
\hline 13 & 13 & 2,3 & 8,90 \\
\hline 14 & 14 & 4,2 & 8,90 \\
\hline 15 & 15 & 2,4 & 8,90 \\
\hline
\end{tabular}


Berdasarkan hasil dari perengkingan nilai saving di atas, maka ditentukanlah rute hasil saving sebagai berikut: a. Rute hasil SavingHeuristic untuk sekali pelayanan (pagi)

Tabel 19. Rute Hasil Saving Heurstic untuk sekali pelayanan

\begin{tabular}{cccc}
\hline \multirow{2}{*}{ Jalur } & Rute & $\begin{array}{c}\text { Jarak } \\
(\mathbf{K m})\end{array}$ & $\begin{array}{c}\text { Sampah } \\
\text { Terangkut }\left(\mathbf{m}^{\mathbf{3}}\right)\end{array}$ \\
\hline Rute 1 & Pool-16-17-19-20-21-22-1-2-3-4-5-6-7-8-9-10-11-12-13- & 26,21 & 6,73 \\
& $14-15-18-23-24-25-26-27-28-29-30-31-32-33-34-35-36-37-$ & & \\
& $38-39-40-41-42-43-44-45-46-47-48-49-50-51-52-53-54-55-$ & & \\
& & & \\
\hline & TPA-Pool & $\mathbf{2 6 , 2 1}$ & $\mathbf{6 , 7 3}$ \\
\hline
\end{tabular}

Berdasarkan hasil perhitungan saving, diperoleh total jarak tempuh alat angkut sejauh 26,21 Km dengan julah samapah yang terangkut sebesar $6,73 \mathrm{~m}^{3}$. Hal ini menandakan bahwa terjadi penghematan total jarak tempuh sebesar $0,62 \mathrm{Km}$ dari jarak tempuh awal yang dilalui alat angkut yakni sejauh 26,83 $\mathrm{Km}$. Berdasarkan rute hasil SavingHeuristicyang diperoleh maka biaya operasional(pemakaian bahan bakar) untuk satu kali pelayanan sampah (pelayanan

pagi) diperoleh: $\frac{26,21 \mathrm{~km}}{6,5 \mathrm{~km}} \times R p 5.500=$ $R p 22.177,69$ atau 4,03 liter.

Untuk menghindari nilai decimal pada biaya operasional, maka Dinas Lingkungan Hidup dapat mengalokasikan biaya operasional (biaya bahan bakar) alat angkut untuk 5 liter sehingga diperoleh besaran biaya operasional (biaya bahan bakar) sebesar 5 liter x Rp 5.500 = Rp 27.500,00/hari atau Rp 55.000,00 untuk 2 hari.

b. Rute hasil savingHeuristic untuk dua kali pelayanan (pagi dan sore)

Tabel 20. Rute hasil SavingHeuristic untuk dua kali pelayanan

\begin{tabular}{clc}
\hline Jalur & \multicolumn{1}{c}{ Rute } & Jarak (Km) \\
\hline Rute 1 & Pool-16-17-19-20-21-22-1-2-3-4-5-6-7-8-9-10-11-12- & 26,09 \\
& $13-14-15-18-23-24-25-26-27-28-T P A-P o o l$ & \\
\hline Rute 2 & $\begin{array}{l}\text { Pool-29-30-31-32-33-34-35-36-37-38-39-40-41-42-43- } \\
\text { 44-45-46-47-48-49-50-51-52-53-54-55-TPA-Pool }\end{array}$ & 20,36 \\
\hline & \multicolumn{2}{c}{ Total Jarak } \\
\hline
\end{tabular}

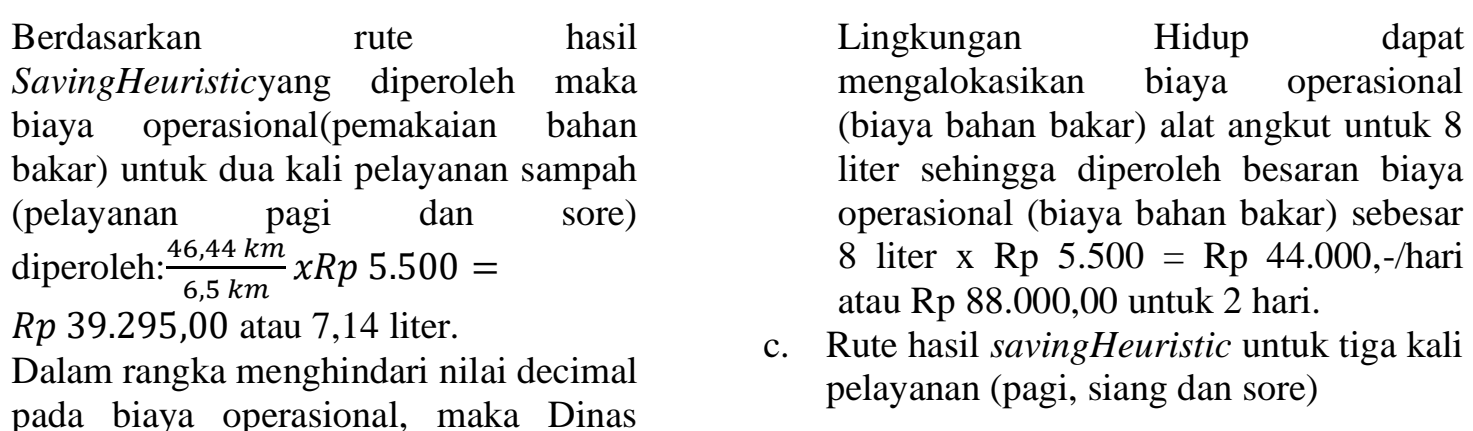


Tabel 21. Rute hasil savingHeuristic untuk tiga kali pelayanan

\begin{tabular}{clc}
\hline Jalur & \multicolumn{1}{c}{ Rute } & Jarak (Km) \\
\hline Rute 1 & $\begin{array}{l}\text { Pool-16-17-19-20-21-22-1-2-3-4-5-6-7-8-9-10- } \\
\text { 11-12-TPA-Pool }\end{array}$ & 25,64 \\
\hline Rute 2 & $\begin{array}{l}\text { Pool-13-14-15-18-23-24-25-26-27-28-29-30- } \\
\text { 31-32-33-34-35-36-TPA-Pool }\end{array}$ & 22,41 \\
\hline Rute 3 & $\begin{array}{l}\text { Pool-37-38-39-40-41-42-43-44-45-46-47-48- } \\
\text { 49-50-51-52-53-54-55-TPA-Pool }\end{array}$ & 20,44 \\
\hline \multicolumn{1}{c}{ Total Jarak } & $\mathbf{6 8 , 4 9}$ \\
\hline
\end{tabular}

Berdasarkan rute hasil SavingHeuristicyang diperoleh maka biaya operasional(pemakaian bahan bakar) untuk tiga kali pelayanan sampah (pelayanan pagi, siang dan sore) diperoleh: $\frac{68,49}{6,5 \mathrm{~km}} \times R p 5.500=$

$R p$ 57953,08 atau 10,51 liter.

Agar tidak memperoleh nilai decimal pada biaya operasional, maka Dinas Lingkungan Hidup dapat mengalokasikan biaya operasional (biaya bahan bakar) alat angkut untuk 11 liter sehingga diperoleh besaran biaya operasional (biaya bahan bakar) sebesar 11 liter $x$ Rp $5.500=$ Rp 60.500,-/hari atau $\mathrm{Rp} 121.000,-$ untuk 2 hari.

\section{KESIMPULAN DAN SARAN \\ Kesimpulan}

Adapun kesimpulan dari penelitian ini adalah sebagai berikut :

- Pola rute pelayanan pengangkutan sampah yang efektif di Kota Baubauadalah pola rute hasil savingHeuristic yaitu:

- Kecamatan Murhum (jalur 1)

- Pola rute untuk satu kali pelayanan(pelayanan pagi) sejauh 27,00 km dengan penghematan jarak sejauh 1,19 $\mathrm{km}$ dari rute awal.

- Pola rute untuk dua kali pelayanan(pelayanan pagi dan siang) sejauh 50,62 km dimana rute 1 sejauh $26,04 \mathrm{~km}$ dan rute 2 sejauh 24,58 kmdengan penghematan jarak sejauh 2,55 $\mathrm{km}$ dari rute awal.

- Pola rute untuk tiga kali pelayanan (pelayanan pagi, siang dan sore) sejauh 74,05 km dimana rute 1 sejauh $25,44 \mathrm{~km}$, rute 2 sejauh $26,07 \mathrm{~km}$ dan rute 3 sejauh 22,54 kmdengan penghematan jarak sejauh 1,71 $\mathrm{km} / 3$ kali rute.

- Kecamatan Murhum (jalur 2)

- Pola rute untuk satu kali pelayanansejauh $27,47 \quad \mathrm{~km}$ dengan penghematan jarak sejauh $0,44 \mathrm{~km}$ dari rute awal.

- Pola rute untukdua kali rute pelayanan sejauh 49,41 km dimana rute 1 sejauh $25,88 \mathrm{~km}$ dan rute 2 sejauh $23,53 \mathrm{~km}$ denganpenghematan jarak sejauh $3,11 \mathrm{~km}$ dari rute awal.

- Pola rute untuk tiga kali pelayanan sejauh $71,58 \mathrm{~km}$ dimana rute 1 sejauh $24,38 \mathrm{~km}$, rute 2 sejauh $24,38 \mathrm{~km}$ dan rute 3 sejauh 22,82 km dengan penghematan jarak sejauh 1,60 $\mathrm{km}$ dari rute awal.

- Kecamatan Batupoaro (Jalur 3)

- Pola rute untuk satu kali pelayanan sejauh $26,21 \mathrm{~km}$ dengan penghematan jarak sejauh $0,44 \mathrm{~km}$ dari rute awal.

- Pola rute untuk dua pelayanansejauh $\quad 46,44 \quad \mathrm{~km}$ dimana rute 1 sejauh $26,09 \mathrm{~km}$ dan rute 2 sejauh 20,36 kmdenganpenghematan jarak sejauh $0,62 \mathrm{~km}$ dari rute awal.

- Pola rute untuk tiga kali pelayanan sejauh $68,49 \mathrm{~km}$ dimana rute 1 sejauh $25,64 \mathrm{~km}$, rute 2 sejauh 24,38 $\mathrm{km}$ dan rute 3 sejauh 20,44 km denganpenghematan jarak sejauh $0,69 \mathrm{~km}$ dari rute awal.

- Biaya operasional yang harus ditanggung oleh Dinas Lingkungan Hidup Kota Baubau yang diakibatkan oleh pola rute pelayananyang terbentuk adalah :

- Kecamatan Murhum (Jalur 1) 
- Biaya operasional untuk satukali pelayanan sebesar Rp 27.500,00 perhari atau Rp 55.000,00 per dua hari.

- Biaya operasional untuk duakali pelayanan sebesar Rp 44.000,00 perhari atau $\mathrm{Rp} 88.000,00$ per dua hari.

- Biaya operasional untuk tigakali pelayanan sebesar $\mathrm{Rp} 66.000,00$ perhari atau $\mathrm{Rp} 132.000,00$ per dua hari.

- Kecamatan Murhum (Jalur 2)

- Biaya operasional untuk satukali pelayanan sebesar Rp 27.500,00 perhari atau Rp 55.000,00 per dua hari.

- Biaya operasional untuk duakali pelayanan sebesar Rp 44.000,00 perhari atau $\mathrm{Rp} 88.000,00$ per dua hari.

- Biaya operasional untuk tigakali pelayanan sebesar Rp 66.000,00 perhari atau $\mathrm{Rp} 132.000,00$ per dua hari.

- Kecamatan Batupoaro (Jalur 3)

- Biaya operasional untuk satukali pelayanan sebesar $\mathrm{Rp} 27.500,00$ perhari atau $\mathrm{Rp} 55.000,00$ per dua hari.

- Biaya operasional untuk duakali pelayanan sebesar Rp 44.000,00 perhari atau $\mathrm{Rp} 88.000,00$ per dua hari.

- Biaya operasional untuk tigakali pelayanan sebesar Rp $60.500,00$ perhari atau $\mathrm{Rp} 121.000,00$ per dua hari.

\section{DAFTAR PUSTAKA}

Anonim, 2002.Tata cara Teknik Operasional Pengolahan Sampah Perkotaan (SNI 19-2454-2002). Badan Standar Nasional, Jakarta.

Chopra, Sunil and Peter Meindl, 2001: Supply Chain Management (Strategy, Planning, and Operation), Upper Saddle River, New Jersey.
Dinas Pertamanan Pemakaman Dan Pemadam Kebakaran Kota Baubau, 2014.Data Sistem Pengangkutan Sampah Kota Baubau.

Dyah Ernawati, dkk. 2012. Analisis Komposisi, Jumlah dan Pengembangan Strategi Pengelolaan Sampah

Ghiani, Gianpaolo; Gilbert Laporte, and Roberto Musmano, 2004: Introduction to Logistics Systems Planning and Control, John Willey \& Sons LTD, England.

Hapsari, Miranda A., 2006: Penerapan Savings Heuristic Dalam Memecahkan Masalah Vehicle Routing Problem (VRP) Di Harian Umum Lintas Sumedang, Jurusan Teknik Industri Fakultas Teknik, Universitas Pasundan, Bandung.

Manik, 2009.Pengelolaan Lingkungan Hidup. Jakarta: Djambatan

Sianipar, Mariana; David Fu'aini; Wahyu Sutopo; dan Muhammad Hisjam, 2017, Penentuan Rute Kendaraan Menggunakan Metode Clark And Wright Saving Heuristic (Studi Kasus: PT. Sinar Sosro), Performa Vol. 16, No. 2.

Perwitasari, 2012, Penentuan Rute Pengambilan Sampah Di Kota Merauke Dengan Kombinasi Metode Eksak Dan Metode Heurstic, Jurnal Ilmiah Mustek Anim Ha, Vol. 1 No. 2.

Pujawan, I Nyoman. 2004. Supply Chain Management, Edisi Pertama. Surabaya : Guna Widya

Sejati, 2009. Pengelolahan Sampah Terpadu: Dengan Sistem Node Sub Point. Center Point. Yogyakarta: Kanisius.

Suhardimo. 2014. Analisis Timbulan, Sarana dan Prasarana Pengumpulan Sampah Di Kota Baubau

Tarliah D, Tjutju dan Ahmad Dimyati. 2004. Operations Research (ModelModel Pengambilan Keputusan). Edisi Kedua. Cetakan Ketujuh. Bandung : Sinar Baru Algensindo 